\title{
INDEX To Volume 28 (2010)
}

\section{Articles}

BALL, David. The Tracts of May (Vol. 28, No. 1, 77)

COWANS, Jon. Black and White on the Silver Screen: Views of Interracial Romance in French Films and Reviews since the 1980s (Vol. 28, No. 3, 46)

LEQUET, Stephen. Nicolas Sarkozy et le gaullisme (Vol. 28, No. 1, 92)

MACMASTER, Neil. Identifying 'Terrorists' in Paris: A Political Experiment with IBM Machines during the Algerian War (Vol. 28, No. 3, 23)

MARTHALER, Sally. La course au centre: Policy Convergence and Partisanship in France, 1981-2002 (Vol. 28, No. 2, 75)

SHIELDS, James. The Far-Right Vote in France: From Consolidation to Collapse? (Vol. 28, No. 1, 25)

TOLOUDIS, Nicholas. Tocqueville's Guizot Moment (Vol. 28, No. 3, 1)

VAILLANT, Derek W. La Police de l'Air: Amateur Radio and the Politics of Aural Surveillance in France, 1921-1940 (Vol. 28, No. 1, 1)

WATERS, Sarah. Globalization, the Confédération paysanne, and Symbolic Resistance (Vol. 28, No. 2, 96)

\section{DOSSIER: Claude Lévi-Strauss in Wartime New York: The Genesis of} STRUCTURALISM

DEBAENE, Vincent. "Like Alice Through the Looking Glass": Claude Lévi-Strauss in New York (Vol. 28, No. 1, 46)

JEANPIERRE, Laurent. Les structures d'une pensée d'exil: La formation du structuralisme de Claude Lévi-Strauss (Vol. 28, No. 1, 58)

\section{DOSSIER: The Future of France}

CHAUVEL, Louis. The Long-Term Destabilization of Youth, Scarring Effects, and the Future of the Welfare Regime in Post-Trente Glorieuses France (Vol. 28, No. 3, 74)

GOLDHAMMER, Arthur. The Future of French Culture (Vol. 28, No. 3, 97)

LAURENT, Éloi and LAMONT, Michèle. Introduction: Assessing France as a Model of Societal Success (Vol. 28, No. 3, 66)

LAURENT, Éloi. The French Carbon Tax: Autopsy of an Ambition (Vol. 28, No. 3, 114) 


\section{SPECIAL ISSUE ON Simone De BeAuvoir: Engagements, ConteXts, RECONSIDERATIONS}

BHABHA, Homi. Introduction (Vol. 28, No. 2, 1)

COFFIN, Judith. Beauvoir, Kinsey, and Mid-Century Sex (Vol. 28, No. 2, 18)

JARDINE, Alice. What Feminism? (Vol. 28, No. 2, 66)

MCDONALD, Christie. The Death of Maternity? Simone de Beauvoir's A Very Easy Death (Vol. 28, No. 2, 56)

SULEIMAN, Susan Rubin. Memory Troubles: Remembering the Occupation in Simone de Beauvoir's Les Mandarins (Vol. 28, No. 2, 4)

SURKIS, Judith. Ethics and Violence: Simone de Beauvoir, Djamila Boupacha, and the Algerian War (Vol. 28, No. 2, 38)

\section{Review Essays}

COLE, Joshua. Massacres and Their Historians: Recent Histories of State Violence in France and Algeria in the Twentieth Century (Vol. 28, No. 1, 106)

THOMPSON, Victoria E. Biographers of Paris: Cultural Approaches to the Modern City (Vol. 28, No. 2, 118)

\section{Book Reviews}

CAMISCIOLI, Elisa. Races, racisme et antiracisme dans les années 1930 by Carole Reynaud Paligot (Vol. 28, No. 1, 133)

CONKLIN, Alice L. Les Enfants de la colonie: Les métis de l'Empire français entre sujétion et citoyenneté by Emmanuelle Saada (Vol. 28, No. 2, 134)

DAVID, Lepoutre. La France a peur. Une histoire sociale de l'«insécurité » by Laurent Bonelli (Vol. 28, No. 2, 146)

DONAHUE, Katherine C. Judging Mohammed: Juvenile Delinquency, Immigration, and Exclusion at the Paris Palace of Justice by Susan J. Terrio (Vol. 28, No. 3, 149)

EARLE, Jason. Surrealism and the Art of Crime by Jonathan P. Eburne (Vol. 28, No. 2, 137)

FORD, Caroline. An Empire Divided: Religion, Republicanism, and the Making of French Republicanism, 1880-1914 by J. P. Daughton (Vol. 28, No. 3, 131)

GAMBLE, Harry. The Moroccan Soul: French Education, Colonial Ethnology, and Muslim Resistance, 1912-1956 by Spencer D. Segalla (Vol. 28, No. 3, 136)

HANNA, Martha. Race and War in France: Colonial Subjects in the French Army, 1914-1918 by Richard S. Fogarty (Vol. 28, No. 3, 133)

HAYNES, Christine. The New Bibliopolis: French Book Collectors and the Culture of Print, $1880-1914$ by Willa Z. Silverman (Vol. 28, No. 3, 128)

JANKOWSKI, Paul. Reconciling France against Democracy: The Croix de Feu and the Parti Social Français, 1927-1945 by Sean Kennedy (Vol. 28, No. 2, 140)

MAILLARD, Jacques de. Governing and Governance in France by Alistair Cole (Vol. 28, No. 1,139$)$

MANN, Gregory. Boundaries of the Republic: Migrant Rights and the Limits of Universalism in France, 1918-1940 by Mary Dewhurst Lewis (Vol. 28, No. 1, 130)

MATHY, Jean-Philippe. French Theory: How Foucault, Derrida, Deleuze, \& Co. Transformed the Intellectual Life of the United States by François Cusset (Vol. 28, No. $2,143)$ 
MATLOCK, Jann. The Great Stink of Paris and the Nineteenth-Century Struggle against Filth and Germs by David S. Barnes (Vol. 28, No. 3, 125)

POPKIN, Jeremy D. France after Revolution: Urban Life, Gender, and the New Social Order by Denise Z. Davidson (Vol. 28, No. 1, 127)

ROSENBERG, Clifford. Liberté, égalité, discriminations: L"Identité nationale' au regard de l'histoire by Patrick Weil (Vol. 28, No. 3, 143)

SCHNEIDER, Ulrich Johannes. From Revolution to Ethics: May 1968 and Contemporary French Thought by Julian Bourg (Vol. 28, No. 1, 135)

SHOVLIN, John. Reimagining Politics After the Terror: The Republican Origins of French Liberalism by Andrew Jainchill (Vol. 28, No. 3, 123)

WELCH, Cheryl B. Critical Republicanism: The Hijab Controversy and Political Philosophy by Cécile Laborde (Vol. 28, No. 3, 145)

WRIGHT, Julian. Shades of Indignation: Political Scandals in France, Past and Present by Paul Jankowski (Vol. 28, No. 3, 140)

\section{INDEX OF BOOKS REVIEWED}

BARNES, David S. The Great Stink of Paris and the Nineteenth-Century Struggle against Filth and Germs reviewed by Jann Matlock (Vol. 28, No. 3, 125)

BONELLI, Laurent. La France a peur. Une histoire sociale de $l^{\prime}$ ' insécurité » reviewed by David Lepoutre (Vol. 28, No. 2, 146)

BOURG, Julian. From Revolution to Ethics: May 1968 and Contemporary French Thought reviewed by Ulrich Johannes Schneider (Vol. 28, No. 1, 135)

COLE, Alistair. Governing and Governance in France reviewed by Jacques de Maillard (Vol. 28, No. 1, 139)

CUSSET, François. French Theory: How Foucault, Derrida, Deleuze, \& Co. Transformed the Intellectual Life of the United States reviewed by Jean-Philippe Mathy (Vol. 28, No. 2, 143)

DAUGHTON, J. P. An Empire Divided: Religion, Republicanism, and the Making of French Republicanism, 1880-1914 reviewed by Caroline Ford (Vol. 28, No. 3, 131)

DAVIDSON, Denise Z. France after Revolution: Urban Life, Gender, and the New Social Order reviewed by Jeremy D. Popkin (Vol. 28, No. 1, 127)

DEWHURST LEWIS, Mary. Boundaries of the Republic: Migrant Rights and the Limits of Universalism in France, 1918-1940 reviewed by Gregory Mann (Vol. 28, No. 1, 130)

EBURNE, Jonathan P. Surrealism and the Art of Crime reviewed by Jason Earle (Vol. 28, No. 2, 137)

FOGARTY, Richard S. Race and War in France: Colonial Subjects in the French Army, 1914-1918 reviewed by Martha Hanna (Vol. 28, No. 3, 133)

JAINCHILL, Andrew. Reimagining Politics After the Terror: The Republican Origins of French Liberalism reviewed by John Shovlin (Vol. 28, No. 3, 123)

JANKOWSKI, Paul. Shades of Indignation: Political Scandals in France, Past and Present reviewed by Julian Wright (Vol. 28, No. 3, 140)

KENNEDY, Sean. Reconciling France against Democracy: The Croix de Feu and the Parti Social Français, 1927-1945 reviewed by Paul Jankowski (Vol. 28, No. 2, 140)

LABORDE, Cécile. Critical Republicanism: The Hijab Controversy and Political Philosophy reviewed by Cheryl B. Welch (Vol. 28, No. 3, 145)

REYNAUD PALIGOT, Carole. Races, racisme et antiracisme dans les années 1930 reviewed by Elisa Camiscioli (Vol. 28, No. 1, 133)

SAADA, Emmanuelle. Les Enfants de la colonie: Les métis de l'Empire français entre sujétion et citoyenneté reviewed by Alice L. Conklin (Vol. 28, No. 2, 134) 
SEGALLA, Spencer D. The Moroccan Soul: French Education, Colonial Ethnology, and Muslim Resistance, 1912-1956 reviewed by Harry Gamble (Vol. 28, No. 3, 136)

SILVERMAN, Willa Z. The New Bibliopolis: French Book Collectors and the Culture of Print, 1880-1914 reviewed by Christine Haynes (Vol. 28, No. 3, 128)

TERRIO, Susan J. Judging Mohammed: Juvenile Delinquency, Immigration, and Exclusion at the Paris Palace of Justice reviewed by Katherine C. Donahue (Vol. 28, No. 3, 149)

WEIL, Patrick. Liberté, égalité, discriminations: L'Identité nationale' au regard de l'histoire reviewed by Clifford Rosenberg (Vol. 28, No. 3, 143) 